\title{
The Benefits of the Application of Activity Based Cost System - Field Study on Manufacturing Companies Operating In Allahabad City - India
}

\author{
Mr. Shaban E. A. Salem ${ }^{1}$, Dr. Shabana Mazhar ${ }^{2}$ \\ ${ }^{I}$ (Ph.D. Research Scholar, Business Administration Department, Joseph School of Business Studies, SHIATS, \\ India) \\ ${ }^{2}$ (Associate Professor, Business Administration Department, Joseph School of Business Studies, SHIATS, India)
}

\begin{abstract}
This study aims to identifying the benefits of the application of ABC system throuth a field study on companies operating in allahabad-india. In order to achieve such aims, a questionnaire was developed and distributed to the population of study. Spss program was used in the analysis.

The study concluded with some results. The most apparent is that the expected benefits of behind the application of $A B C$ system from the standpoint of these companies are $A B C$ system helps to calculate the cost of the product more accurately, leads to enhance the costs control and $A B C$ system provides the financial and non-financial information that help in taking sound administrative decisions such as fixing selling prices of products and exclusion of activities that do not add value to the product.

The study recommends the companies should start gradually in applying $A B C$ system by persuading the management of these companies on the importance of application the system because of its advantages and benefits.
\end{abstract}

Keywords: ABC System, Traditional Cost System, Overhead.

\section{Introduction}

In the present era, companies produce wide range of products and direct labour represent only a small percentage of total costs, the intense global competition has made decision errors due to poor cost information more problem and more costly, also in this computer age of advancing technologies and automation, the proportion and importance of overhead in the manufacturing operations is increasing and direct costs are being relegated to the background. Overhead is the aggregate of indirect materials, indirect wages and indirect expenses (M. N. Arora,2013).

it is a well-known fact that the traditional cost systems utilize a single volume-based cost driver, this is the reason why the traditional cost system distorts the cost of products (V. K. Saxena, et al, 2011). In most cases this type of costing system assigns the overhead costs to products on the basis of their relative usage of direct labour. For this reason traditional cost systems often report inaccurate product costs. Therefore, there is a need for a more sophisticated system of accounting for overhead so that more accurate costs of products and services may be ascertained.

activity based cost system which known as (ABC system) is an alternative to traditional way of overhead accounting, it is an upcoming and more refined approach of charging overhead to ascertain more accurate product costs (V. Rajasekaran, et al, 2011). ABC system arose in the 1980s from the increasing lack of relevance of traditional cost accounting methods, it is developed by cooper and kalpan for assigning overhead to end products, jobs and processes, it aims to rectify the problem of inaccurate cost information due to selection of wrong bases of overhead apportionment (Charles t. Horngren,et al, 2013).

this study comes as an attempt to explain the concept of $\mathrm{ABC}$ system, in addition to determine the expected benefits of application of $\mathrm{ABC}$ system in companies under study.

\section{The Study Problem}

In light of the growing interest in topic of importance and benefits of the application of $\mathrm{ABC}$ system in manufacturing companies this study problem attempts to answer the following question: are there any benefits from the application of $\mathrm{ABC}$ in companies?

\section{The Study Objectives}

This study aims to attain the following objectives:

- To highlight the concept of $\mathrm{ABC}$ system in addition to know the advantages and disadvantages of $\mathrm{ABC}$ system.

- Being acquainted with the benefits of application of $\mathrm{ABC}$ system in companies. 


\section{Literature Review}

There are many studies and previous researches which dealt with various aspects of the $\mathrm{ABC}$ system, some of these studies which addressed the benefits of ABCsystem as following:

Lee (1990): This study aimed to assess the effectiveness of the application of $A B C$ at cal electronic circuits -u.s. company-, where this study indicated that the company has reaped positive results exceeded the exact cost of the product to include increased production efficiency and competitiveness of this company in addition to increasing the efficiency of the decision-making process as a result of the provision of accurate information about the costs of products.

Pigott (1992): This study stated that the implementation of this system has resulted in achieving several advantages was the most prominent re-pricing of products after was reached to cost products more accurate, as proven that application of this system that traditional systems that were applied in this company tend to increase the certain products costs and reduce the other products costs, for example found that 38 of products were inflated costs by up to $55 \%$ and the cost of about 85 of products were reduced by up to $92.5 \%$ which necessitated re-analyze and evaluate the profitability of different products.

Turney Peter and Stratton Alan (1992): This study was applied on one of the companies which is using the $\mathrm{ABC}$ system to improve the decisions of products costs and provide needed information to rationalize the efforts of continuous improvement. This study concluded to several of the most important results that process of linking information with system $\mathrm{ABC}$ led to facilitate the process of preparing the total quality costs in company also this study found that $\mathrm{ABC}$ system helps to reduce costs and improve the quality of informations.

As per kaplan (1992): The need to $A B C$ system data is not only for managers to be able to progress in conditions of prevailing competitive environment, but in order achieve integration of the information system with the other rest systems and in addition, $\mathrm{ABC}$ system helps companies to understand the relationship between programs of improvement process and increase profit.

Merz and Hardy (1993): This study indicated that $A B C$ system enabled accountants to involve in product design process also help engineers and production officials in understanding the nature of the behavior of industry costs in addition, ABC system leads to a high level of professional life for accountants and produce good cost information.

Cooper and Kaplan (1998): This study found that the application of ABC system will lead to exclude activities that do not add value to the product unit and keep the activities that add value to the product unit which in turn lead to reduce the cost of products.

This study showed that

Narayanan and Ratna (1999): this study showed that the information provided by the ABC system useful in the decision-making process related to the products and customers alike, where the system works on the accuracy of the products pricing and the dealing cost with customers. In addition, this study concluded that if the company applied $\mathrm{ABC}$ system will achieve two important benefits: firstly, working on the development of the internal processes of the company, which lead to raise the efficiency of the use of resources and secondly, reduce costs in general and in particular the additional costs, which enhances the ability of the company to achieve more profitability in mixed products.

Neumann et al (2004): This study aims to use activities based costing system as an alternative to the traditional cost system, in order to develop new ways to manage and control the costs. The study concluded multiple results, including: $\mathrm{ABC}$ system provides an accurate tool to manage and measure the costs efficiently, especially in the light of globalization and recent trends towards the intensity of competition.

\section{Concept of ABC System.}

Cooper and Kaplan has presented $\mathrm{ABC}$ system project in the $1980_{\mathrm{s}}$ as an alternative to be more suitable to the allocation of indirect costs to end products than the traditional cost system, it aims to rectify the problem of inaccurate cost information due to selection of wrong bases of indirect cost apportionment. In the words of Cooper and Kaplan, $\mathrm{ABC}$ system calculate the costs of individual activities and assign costs to cost objects such as products and services on the basis of activities undertaken to produce each product and service. 
According to C.I.M.A., London, $\mathrm{ABC}$ system is: Cost attribution to cost units on the basis of benefits received from indirect activities, i.e., ordering, setting up, assuring quality, etc (Arora, 2013). ABC system is that costing in which costs are first traced to activities and then to products, $\mathrm{ABC}$ is costing system which focuses on activities performed to produce products (Jawahar Lal , 2009).

The logic behind $\mathrm{ABC}$ system is products consume activities and activities consume resources. The relationships between activities and products have been shown as follows:

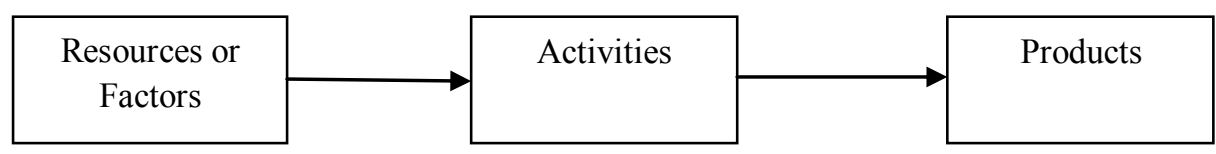

Fig 1: ABC System Process.

\section{Advantages and Disadvantages of ABC System.}

1- Advantage of $\mathrm{ABC}$ System.

ABC system offers the following advantages (Jawahar Lal, 2009):

- $\mathrm{ABC}$ system brings accuracy and reliability in product cost determination by focusing on cause and effect relationship in the cost incurrence. It recognizes that is activities which cause costs, not products and it is product which consumes activities.

- In advanced manufacturing environment and technology where support functions overhead constitute a large share of total costs, $\mathrm{ABC}$ system provides more realistic product costs.

- $\mathrm{ABC}$ system identifies the real nature of cost behavior and helps in reducing costs and identifying activities which do not add value to the product. With $\mathrm{ABC}$ system, managers are able to control many fixed overhead costs by exercising more control over the activities which have caused these fixed overhead costs. This is possible since behavior of many fixed overhead costs in relation to activities now become more visible and clear.

- $\mathrm{ABC}$ system uses multiple cost drivers, many of which are transaction based rather than product volume. Further, $\mathrm{ABC}$ system is concerned with all activities within and beyond the factory to trace more overheads to the products.

- $\mathrm{ABC}$ system traces costs to areas of managerial responsibility, processes, customers, department besides the product costs.

- $\mathrm{ABC}$ system improves greatly the manager's decision making as they can use more reliable product cost data.

- $\mathrm{ABC}$ system helps usefully in fixing selling prices of products as more correct data of product cost is now readily available.

- $\mathrm{ABC}$ system products reliable and correct product cost data in cause of greater diversity among the products manufactured such as low-volume products, high-volume products. Traditional costing system is likely to bring errors and approximation in product cost determination due to using arbitrary apportionment and absorption methods.

- $\mathrm{ABC}$ system provides cost driver rates and information on transaction volumes which are very useful to management and performance appraisal of responsibility centers. Cost driver rates can be used advantageously for the design of new products or existing products as they indicate overhead costs that are likely to be applied in costing the product.

- $\mathrm{ABC}$ system provides not only a base for calculating more accurate product cost but also a mechanism for managing costs.

\section{2- Disadvantage of ABC System.}

ABC system typically provides better information than traditional overhead allocation process. Still it is not the presence for all managerial problems. Following criticism has been leveled against ABC system (Jawahar Lal, 2009) and ( Saxena, et al, 2010):

- $\mathrm{ABC}$ system has numerous cost pool and multiple cost drivers and therefore can be more complex than traditional product costing systems.

- Some difficulties emerge in the implementation of ABC system, such as selection of cost drivers, assignment of common costs, varying cost driver rates etc.

- $\mathrm{ABC}$ system has different level of utility for different organization such as large manufacturing firm can use it more usefully than the smaller firms. Also, it is likely that firms depending on cost-plus pricing can take advantages from $\mathrm{ABC}$ system as it gives accurate product cost. But those firms who use market based prices may not favour $\mathrm{ABC}$ system. The level of technology and manufacturing environment prevailing in different firms also effect the application of $\mathrm{ABC}$ system. 
- $\mathrm{ABC}$ system implementation requires significant amount of time and cost to implement.

- An environment of change must be created for implementation of $\mathrm{ABC}$ system. It requires overcoming a variety of individuals, organisation and environmental barriers as follows:

- Fear of unknown and shift in status quo,

- Potential loss of status,

- A necessity to learn new skill.

- To overcome these barriers, a firm must recognise that these barriers exist. The causes of the barriers should be investigated. Then organisation should communicate information about, 'what', 'why' and 'how' of $\mathrm{ABC}$ system to all concerned parties. It presents limitation of $\mathrm{ABC}$ system.

- Employees and managers must be educated in some non-traditional techniques that include new terminology, concepts and performance measurements.

- Additional time will be required to analyse the activities taking place in the activity centers, trace cost to those activities and determining the cost drivers.

\section{Nature of Data}

\section{Study Methodology}

The data required for the study has been collected from secondary sources by relying on the scientific books, published papers and researches.

\section{Data Collection Method}

The present study has been adopted on the comprehensive survey of the population of the study which consists of entire the manufacturing companies operating in allahabad - india, whether they government or private and large or medium companies. The population of study consists of $\mathbf{1 8}$ companies.

To gather data a questionnaire had been designed and distributed on the population of study a questionnaire for each company. The questionnaire includes a set of questions with aim to explore the views of the manufacturing companies about the expected benefits from the application of $\mathrm{ABC}$ system in these companies.

\section{Findings/Discussions}

The study data has been analyzed by using spss program (statistical packing for social sciences) and the following table showed the results:

Table 1: Frequency Distribution and Percentages of the Responses of the Study Participants about the Benefits of Application of ABC System in Companies.

\begin{tabular}{|c|c|c|c|c|c|c|c|}
\hline \multirow[t]{2}{*}{ No } & \multirow[t]{2}{*}{ Questions } & Percentage $\%$ & \multirow{2}{*}{$\begin{array}{l}\text { Strongly } \\
\text { agree }\end{array}$} & \multirow[t]{2}{*}{ Agree } & \multirow[t]{2}{*}{ Neutral } & \multirow[t]{2}{*}{ Disagree } & \multirow{2}{*}{$\begin{array}{l}\text { Strongly } \\
\text { disagree }\end{array}$} \\
\hline & & Number & & & & & \\
\hline \multirow[t]{2}{*}{1} & \multirow{2}{*}{$\begin{array}{l}\text { ABC system is considered one } \\
\text { of modern systems of cost } \\
\text { accounting }\end{array}$} & Number & 13 & 5 & - & - & - \\
\hline & & Percentage\% & $72.2 \%$ & $27.8 \%$ & - & - & - \\
\hline \multirow[t]{2}{*}{2} & \multirow{2}{*}{$\begin{array}{l}\text { ABC system helps to calculate } \\
\text { the cost of the product more } \\
\text { accurately }\end{array}$} & Number & 11 & 6 & 1 & - & - \\
\hline & & Percentage $\%$ & $61.1 \%$ & $33.3 \%$ & $5.6 \%$ & - & - \\
\hline \multirow[t]{3}{*}{3} & \multirow{3}{*}{$\begin{array}{l}\text { ABC system helps in } \\
\text { understanding the behavior of } \\
\text { costs and thus helps to find out } \\
\text { the causes of indirect costs }\end{array}$} & Number & $\overline{14}$ & 3 & 1 & & \\
\hline & & & & & & & \\
\hline & & Percentage $\%$ & $77.7 \%$ & $16.7 \%$ & $5.6 \%$ & - & - \\
\hline \multirow[t]{2}{*}{4} & \multirow{2}{*}{$\begin{array}{l}\text { Indirect costs accounted for a } \\
\text { large proportion of the cost } \\
\text { structure, which requires } \\
\text { application } \mathrm{ABC} \text { system }\end{array}$} & Number & $\overline{6}$ & 3 & $\overline{6}$ & 3 & - \\
\hline & & Percentage\% & $33.3 \%$ & $16.7 \%$ & $33.3 \%$ & $16.7 \%$ & - \\
\hline \multirow[t]{2}{*}{5} & \multirow{2}{*}{$\begin{array}{l}\text { ABC system identifies the real } \\
\text { nature of cost behaviour and } \\
\text { helps in reducing costs }\end{array}$} & Number & 13 & 5 & - & - & - \\
\hline & & Percentage\% & $72.2 \%$ & $27.8 \%$ & - & - & - \\
\hline \multirow[t]{2}{*}{6} & \multirow{2}{*}{$\begin{array}{l}\text { ABC system helps in tracing } \\
\text { costs to areas of managerial } \\
\text { responsibilit }\end{array}$} & Number & 10 & 3 & 5 & - & - \\
\hline & & Percentage $\%$ & $55.6 \%$ & $16.7 \%$ & $27.8 \%$ & - & - \\
\hline
\end{tabular}




\begin{tabular}{|c|c|c|c|c|c|c|c|}
\hline \multirow[t]{2}{*}{7} & \multirow[t]{2}{*}{$\begin{array}{l}\text { ABC system leads to enhance } \\
\text { the costs control }\end{array}$} & Number & 15 & 3 & - & - & - \\
\hline & & Percentage\% & $83.3 \%$ & $16.7 \%$ & - & - & - \\
\hline \multirow[t]{2}{*}{8} & \multirow[t]{2}{*}{$\begin{array}{l}\text { ABC system provides the } \\
\text { financial and non-financial } \\
\text { information that help in taking } \\
\text { sound administrative decisions }\end{array}$} & Number & 10 & 4 & 4 & - & - \\
\hline & & Percentage\% & $55.6 \%$ & $22.2 \%$ & $22.2 \%$ & - & - \\
\hline \multirow[t]{2}{*}{9} & \multirow[t]{2}{*}{$\begin{array}{l}\text { ABC system improves greatly } \\
\text { the manager's decision making } \\
\text { as they can use more reliable } \\
\text { product cost data }\end{array}$} & Number & 11 & 4 & 3 & - & - \\
\hline & & Percentage\% & $61.1 \%$ & $22.2 \%$ & $16.7 \%$ & - & - \\
\hline \multirow[t]{2}{*}{10} & \multirow[t]{2}{*}{$\begin{array}{l}\text { ABC system helps usefully in } \\
\text { fixing selling prices of products }\end{array}$} & Number & 9 & 7 & 1 & 1 & - \\
\hline & & Percentage \% & $50 \%$ & $38.9 \%$ & $5.6 \%$ & $5.6 \%$ & - \\
\hline \multirow[t]{2}{*}{11} & \multirow[t]{2}{*}{$\begin{array}{l}\text { As result of the diversity of the } \\
\text { company's products, which } \\
\text { requires the application of the } \\
\text { ABC system }\end{array}$} & Number & 7 & 5 & 5 & 1 & - \\
\hline & & Percentage\% & $38.9 \%$ & $27.8 \%$ & $27.8 \%$ & $5.6 \%$ & - \\
\hline \multirow[t]{2}{*}{12} & \multirow{2}{*}{$\begin{array}{l}\text { ABC system helps to improve } \\
\text { the production process and the } \\
\text { development of the } \\
\text { performance in co }\end{array}$} & Number & 11 & 6 & 1 & - & - \\
\hline & & Percentage $\%$ & $61.1 \%$ & $33.3 \%$ & $5.6 \%$ & - & - \\
\hline \multirow[t]{2}{*}{13} & \multirow[t]{2}{*}{$\begin{array}{l}\text { ABC system leads to improve } \\
\text { the competitive position of the } \\
\text { companywith other companies }\end{array}$} & Number & 9 & 7 & 2 & - & - \\
\hline & & Percentage \% & $50 \%$ & $38.9 \%$ & 11.1 & - & - \\
\hline \multirow[t]{2}{*}{14} & \multirow[t]{2}{*}{$\begin{array}{l}\text { ABC system leads to the } \\
\text { exclusion of activities that do } \\
\text { not add value to the company }\end{array}$} & Number & 10 & 5 & 2 & 1 & - \\
\hline & & Percentage\% & $55.6 \%$ & $27.8 \%$ & $11.1 \%$ & $5.6 \%$ & - \\
\hline
\end{tabular}

The previous table shows the following results:

- That $100 \%$ of the companies surveyed said that $\mathrm{ABC}$ system is considered one of modern systems of cost accounting.

- That $94.4 \%$ of the companies surveyed said that $\mathrm{ABC}$ system helps to calculate the cost of the product more accurately.

- That $94.4 \%$ of the companies surveyed see that $\mathrm{ABC}$ system helps in understanding the behavior of costs and thus helps to find out the causes of indirect costs.

- That $50 \%$ of the companies surveyed think that indirect costs accounted for a large proportion of the cost structure, which requires application $\mathrm{ABC}$ system.

- That $100 \%$ of the companies surveyed see that $\mathrm{ABC}$ system identifies the real nature of cost behaviour and helps in reducing costs.

- That $72.3 \%$ of the companies surveyed said that $\mathrm{ABC}$ system helps in tracing costs to areas of managerial responsibility.

- That $100 \%$ of the companies surveyed think that $\mathrm{ABC}$ system leads to enhance the costs control.

- That $77.8 \%$ of the companies surveyed said that $\mathrm{ABC}$ system provides the financial and non-financial information that help in taking sound administrative decisions.

- That $83.3 \%$ of the companies surveyed said that $\mathrm{ABC}$ system improves greatly the manager's decision making as they can use more reliable product cost data.

- That $88.9 \%$ of the companies surveyed see that $\mathrm{ABC}$ system helps usefully in fixing selling prices of products.

- That $66.7 \%$ of the companies surveyed think that as result of the diversity of the company's products, which requires the application of the $\mathrm{ABC}$ system.

- That $66.7 \%$ of the companies surveyed think that $\mathrm{ABC}$ system helps to improve the production process and the development of the performance in company. 
- That $88.9 \%$ of the companies surveyed see that $\mathrm{ABC}$ system leads to improve the competitive position of the company with other companies.

- That $83.4 \%$ of the companies surveyed see that $\mathrm{ABC}$ system leads to the exclusion of activities that do not add value to the company.

From the previous results it is clear that the companies under study are consistent with a high degree in the categories (strongly agree and agree) about the benefits of $\mathrm{ABC}$ system, this gives an indication that these companies understand and realize the expected benefits from the application of $\mathrm{ABC}$ system.

The following table shows the mean and standard deviation of the questions related the benefits of application of $\mathrm{ABC}$ system in companies.

Table 2: Mean and Standard Deviation of the Responses of the Study Participants about the Benefits of Application of ABC System in Companies.

\begin{tabular}{|c|c|c|c|}
\hline No & Questions & Mean & Std. Deviation \\
\hline 1 & $\begin{array}{l}\text { ABC system is considered one of modern systems of cost } \\
\text { accounting }\end{array}$ & 4.72 & .46 \\
\hline 2 & $\begin{array}{l}\text { ABC system helps to calculate the cost of the product more } \\
\text { accurately }\end{array}$ & 4.56 & .62 \\
\hline 3 & $\begin{array}{l}\text { ABC system helps in understanding the behavior of costs and } \\
\text { thus helps to find out the causes of indirect costs }\end{array}$ & 4.72 & .57 \\
\hline 4 & $\begin{array}{l}\text { Accounted for indirect costs a large proportion of the cost } \\
\text { structure, which requires application ABC system }\end{array}$ & 3.67 & 1.14 \\
\hline 5 & $\begin{array}{l}\text { ABC system identifies the real nature of cost behaviour and } \\
\text { helps in reducing costs }\end{array}$ & 4.72 & .46 \\
\hline 6 & $\begin{array}{l}\mathrm{ABC} \text { system helps in tracing costs to areas of managerial } \\
\text { responsibility }\end{array}$ & 4.28 & .89 \\
\hline 7 & ABC system leads to enhance the costs control & 4.83 & .38 \\
\hline 8 & $\begin{array}{l}\text { ABC system provides the financial and non-financial } \\
\text { information that help in taking sound administrative decisions }\end{array}$ & 4.33 & .84 \\
\hline 9 & $\begin{array}{l}\text { ABC system improves greatly the manager's decision making as } \\
\text { they can use more reliable product cost data }\end{array}$ & 4.44 & .78 \\
\hline 10 & ABC system helps usefully in fixing selling prices of products & 4.33 & .84 \\
\hline 11 & $\begin{array}{l}\text { As result of the diversity of the company's products, which } \\
\text { requires the application of the ABC system }\end{array}$ & 4 & .97 \\
\hline 12 & $\begin{array}{l}\text { ABC system helps to improve the production process and the } \\
\text { development of the performance in company }\end{array}$ & 4.56 & .62 \\
\hline 13 & $\begin{array}{l}\text { ABC system leads to improve the competitive position of the } \\
\text { company with other companies }\end{array}$ & 4.39 & .70 \\
\hline 14 & $\begin{array}{l}\text { ABC system leads to the exclusion of activities that do not add } \\
\text { value to the company }\end{array}$ & 4.33 & .91 \\
\hline
\end{tabular}

From the above table it is that clear the mean of all the benefits is high, which means that the companies under the study strongly agree and agree with the benefits of application of ABC system in companies, as the values of standard deviation indicate extent of consensus the views of the participants in the study about the questions which relate to benefits of application of $\mathrm{ABC}$ system in companies.

\section{Conclusions}

Based on the study of participants' answers to the inquiry and after analyzing the study data, the study had reached the following conclusions:

- $\mathrm{ABC}$ system arose from increasing lack of relevance in traditional cost accounting methods, where is considered an alternative to traditional way of overhead accounting.

- The logic behind $\mathrm{ABC}$ system is products consume the activities and activities consume the resources.

- All the companies surveyed believe that activity based cost system achieves the following benefits:

- $\mathrm{ABC}$ system helps to calculate the cost of the product more accurately, leads to enhance the costs control and $\mathrm{ABC}$ system provides the financial and non-financial information that help in taking sound administrative decisions such as fixing selling prices of products and exclusion of activities that do not add value to the product.

- $\mathrm{ABC}$ system helps in understanding the behavior of costs and thus helps to find out the causes of overhead in addition, $\mathrm{ABC}$ system helps in tracing costs to areas of managerial responsibility.

- $\mathrm{ABC}$ system helps to improve the production process and development performance in companies in addition $\mathrm{ABC}$ system leads to improve the competitive position of the company with other companies. 


\section{Recommendations}

- Companies should start gradually in applying $A B C$ system by persuading the management of these companies on the importance of application the system because of its advantages and benefits.

- Companies must interest in training programs accountants from both practical and professional, taking into account the development of these programs.

- Companies need to hold significant shifts in order to accommodate the technological changes in the modern business environment and keep abreast of all that is new and useful, and the application of modern costs systems to their importance in the current stage.

\section{References}

[1]. Cooper. R. \& Kaplan. R. (1998). Cost Cutting Activity. Economist, 57-67.

[2]. Charles T. Horngren,Et Al. ( 2013). Cost Accounting. New Delhi. Dorling Kindersley (India) Pvt. Ltd.

[3]. Jawahar Lal. (2009). Cost Accounting. New Delhi: Tata Mcgaw-Hill Publishing.

[4]. Kaplan Robert. (1992). In Defense Of Activity - Based Cost Management. Management Accounting, 58-63.

[5]. Lee. Y. (1990). Activity- Based Costing At Cal Electronic Circuits. Management Accounting. Oct, 36-38.

[6]. M. N. Arora. (2013). Cost Accounting. New Delhi: Vikas Publishing House Pvt Ltd.

[7]. Merz Mike \& Hardy Arlen. (1993). ABC Puts Accountants On Design Team At HP. Management Accounting. Sep, 22-27.

[8]. Narayanan. G. \& Ratna. S. (1999). Activity Based Costing At In Steel Industries. National Bureau Of Economic Research. Working Paper No. 7270.

[9]. Neumann Bruce R., Gerlach James H., Moldaure Edwin., Finch Michael And Olson Christine. (2004). Cost Management Using ABC For IT Activities \& Services. Management Accounting Quarterly, 29-40.

[10]. Pigott D. (1992). ABC In Apharmaceutical Company A Remedy. Management Accounting, 18-21.

[11]. V. K. Saxena \& C. D. Vashist. (2010). Advanced Management Accounting. New Delhi. Sultan Chand \& Sons.

[12]. Turney Peter \& Stratton Alan. (1992). Using ABC To Support Continuous Improvement. Management Accounting, 46-50.

[13]. V.Rajasekaran \& R. Lalitha. (2011). Cost Accounting. New Delhi. Dorling Kindersley (India) Pvt. Ltd. 